\title{
Penerapan Model Pembelajaran Kooperatif Tipe Jigsaw untuk Meningkatkan Hasil Belajar IPA KD Klasifikasi Makhluk Hidup Siswa Kelas VII-D SMP Negeri 1 Gandusari Blitar
}

\author{
Sri Harwidiastuti \\ Program Studi Pendidikan Biologi FPIEK IKIP Budi Utomo \\ Jalan Citandui 46 Malang
}

\begin{abstract}
The process and learning outcomes in grades VII D SMP Negeri 1 Gandusari Blitar is not optimal yet. Marked lack of students cooperation among, crowded situation, and less productive interaction in the classroom. Learning outcomes in science, especially Biology is still unde KKM. The assessment was focused on cognitive domains. Application of Jigsaw cooperative learning model type is believed to improve learning outcomes, as the students be more active. It also can increase students responsibilities and cooperation. By using this method the students be able to respect each other. The purpose of this study is to know the increase of science SMP Negeri 1 Gandusari Blitar grade VII D. This classroom action research was carried out in SMP Negeri 1 Gandusari Blitar grade VII D with the number of 40 students consisting of 20 boys and 20 girls with a low learning outcomes. This research was conducted in three cycles. The indicator of the research is during the process the student is active, And classically $85 \%$ of students get value more than 70 ( $\geq 70$ ). The third class-action research cycle that has been done show the improvement of SMP Negeri 1 Gandusari students grade VII D in first semester 2009/2010 academic year.
\end{abstract}

Keywords: Jigsaw cooperative learning, science learning outcomes

Kurikulum Tingkat Satuan Pendidikan (KTSP) sebagai hasil pembaharuan Kurikulum Berbasis Kompetensi (KBK) menghendaki, bahwa suatu pembelajaran pada dasarnya tidak hanya mempelajari tentang konsep, teori dan fakta tapi juga aplikasi dalam kehidupan sehari-hari. Materi pembelajaran tidak hanya tersusun atas hal-hal sederhana yang bersifat hafalan dan pemahaman, tetapi juga tersusun atas materi yang kompleks yang memerlukan analisis, aplikasi dan sintesis, karena itu guru harus bijaksana dalam menentukan suatu model yang sesuai, yang dapat menciptakan situasi dan kondisi kelas yang kondusif agar proses pembelajaran dapat berlangsung sesuai dengan tujuan yang diharapkan.

Salah satu pembelajaran inovatif dan konstruktif yang dapat menggali pengetahuan siswa secara konkret dan mandiri adalah pembelajaran kooperatif. Penerapan pembelajaran kooperatif menjadikan proses pembelajaran lebih variatif, inovatif dan konstruktif dalam merekonstruksi wawasan pengetahuan dan meningkatkan aktifitas serta hasil belajar siswa. Hal ini juga sesuai dengan tingkat perkembangan mental peserta didik SMP yang masih berada pada fase transisi dari konkret ke formal.

Hasil belajar juga dipengaruhi oleh metode pembelajaran yang digunakan oleh guru. Metode pembelajaran yang baik yaitu metode pembelajaran yang mampu membuat setiap individu siswa mempunyai tanggung jawab untuk menjelaskan di kelompoknya, sehingga ia termotivasi untuk belajar. Namun kenyataan di lapangan menunjukkan bahwa pelaksanaan KTSP masih menemui banyak kendala, sehingga masih banyak proses pembelajaran yang berjalan satu arah dan masih menitikberatkan pada ranah kognitif. Hal ini karena guru yang belum menemukan metode pembelajaran yang tepat.

Pembelajaran kooperatif merupakan model pembelajaran dengan menggunakan sistem pengelompokan/tim kecil antara empat sampai enam orang yang mempunyai latar belakang kemampuan akademik, jenis kelamin, ras, atau suku yang berbeda (heterogen) (Sanjaya, 2008:242). Sementara itu Trianto (2007:42), menyatakan bahwa pembelajaran kooperatif disusun dalam sebuah usaha untuk meningkatkan partisipasi siswa, memfasilitasi 
siswa dengan pengalaman sikap kepemimpinan dan membuat keputusan dalam kelompok, serta memberikan kesempatan kepada siswa untuk berinteraksi dan belajar bersama-sama siswa lain yang berbeda latar belakangnya. Siswa berperan ganda, yaitu sebagai siswa dan sebagai guru.

Salah satu strategi pembelajaran kooperatif adalah Jigsaw, yaitu membagi siswa ke dalam kelompok kecil yang heterogen, setiap siswa mendapatkan tugasnya masing-masing untuk dikerjakan di kelompok ahli sebelum mengajarkan pada teman-temannya, sehingga setiap siswamendapatkanaktifdalampembelajarannya dan saling bekerja sama serta saling membantu sesama teman dalam mencapai kompetensi. Adanya keterlibatan siswa dalam kerja kelompok dengan tugasnya sendiri-sendiri akan meningkatkan motivasi siswa dalam belajar, karena siswa merasa malu jika tidak dapat menyumbangkan pikirannya saat diskusi dalam tim ahli, sehingga di rumah ia harus belajar terlebih dahulu. Selain itu setelah berdiskusi dengan tim ahli ia juga harus menjelaskan/menyampaikan hasil diskusi kepada kelompoknya. Slavin (2009:41) menyatakan bahwa metode-metode pembelajaran kooperatif yang menggunakan tujuan kelompok dan tanggung jawab individual akan meningkatkan prestasi siswa. Sementara itu Mattingly dan Van Sickle (Slavin, 2009:57) menemukan pengaruh yang positif dan substansial dari metode Jigsaw dalam pencapaian prestasi mata pelajaran.

Berpijak pada pendapat para ahli di atas penulis menerapkan pembelajaran kooperatif tipe Jigsaw untuk meningkatkan hasil belajar IPA KD Klasifikasi Makhluk Hidup Siswa Kelas VII-D SMP Negetri 1 Gandusari Blitar tahun pelajaran 2009/2010.

\section{METODE}

Penelitian tindakan kelas ini dilaksanakan di SMP Negeri 1 Gandusari Blitar, tepatnya pada siswa kelas VII-D yang berjumlah 40 siswa terdiri atas 14 siswa laki-laki dan 26 siswa perempuan dengan hasil belajar yang masih rendah. Penelitian ini menerapkan pembelajaran kooperatif tipe Jigsaw. Siswa dibagi dalam kelompok kecil yang heterogen dengan beranggotakan 5 siswa sebanyak delapan kelompok asal. Faktor- faktor yang diteliti meliputi faktor guru dan peserta didik yaitu: (1) faktor guru, yang diamati adalah kinerja guru dalam melaksanakan proses pembelajaran dengan menerapkan pembelajaran kooperatif tipe Jigsaw; (2) faktor siswa, yang diamati adalah aktifitas peserta didik dalam mengikuti proses pembelajaran dan hasil belajar peserta didik.

Desain penelitian tindakan kelas ini terdiri atas tiga siklus. Tiap siklus mencakup empat tahap kegiatan yaitu perencanaan (planning), pelaksanaan tindakan (akting), observasi, dan refleksi(reflecting).Sebelumdilakukan penelitian diadakan kegiatan pra penelitian yaitu: observasi awal dilakukan bertujuan untuk identifikasi masalah, menganalisis penyebab masalah dan menetapkan tindakan pemecahannya. Beberapa kegiatan observasi awal untuk mengidentifikasi masalah yaitu melalui wawancara dengan guru IPA dan melihat langsung proses pembelajaran.

Sumber data penelitian ini adalah siswa dan guru pada saat proses pembelajaran dan setelah proses pembelajaran. Data hasil belajar siswa diambil dengan memberikan tes. Data aktifitas siswa selama pembelajaran diambil dengan menggunakan lembar observasi aktifitas siswa. Data kinerja guru selama pembelajaran diambil dengan menggunakan lembar observasi kinerja guru.

\section{HASIL DAN PEMBAHASAN}

Setiap kegiatan pembelajaran diadakan observasi terhadap keaktifan siswa sebagai alat untuk mengetahui tingkat keterlibatan siswa dalam kegiatan pembelajaran. Keterlibatan siswa dalam kegiatan pembelajaran dapat mempengaruhi pemahaman siswa terhadap materi pelajaran. Saat pelaksanaan penelitian, peneliti dibantu oleh 2 teman guru untuk melaksanakan observasi aktifitas siswa. Data keaktifan siswa selama kegiatan pembelajaran pada setiap siklus disajikan pada Tabel 1 di bawah ini. 
Tabel 1 Hasil Analisis Aktifitas Siswa

TINGKAT KEAKTIFAN PESERTA DIDIK

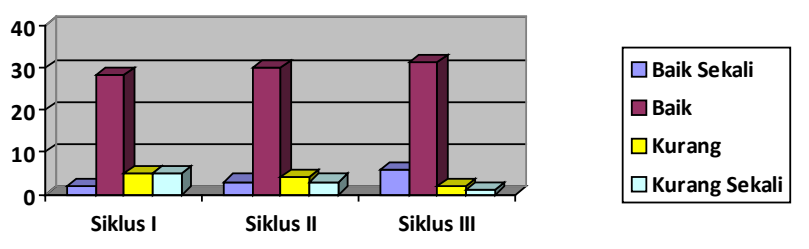

Setiap akhir siklus diadakan tes sebagai alat untuk mengukur pemahaman siswa terhadap materi yang telah disampaikan pada kegiatan pembelajaran. Pelaksanaan tes individual ini dilakukan setiap akhir pembelajaran pada pertemuan terakhir di setiap siklus. Tes tertulis yang digunakan berbentuk pilihan ganda. Ketuntasan belajar individual ditetapkan jika siswa mendapat nilai $\geq 70$. Data hasil tes setiap akhir siklus dan sebelum pelaksanaan tindakan disajikan dalam Tabel 2 di bawah ini.

Tabel 2 Hasil Tes Setiap Siklus
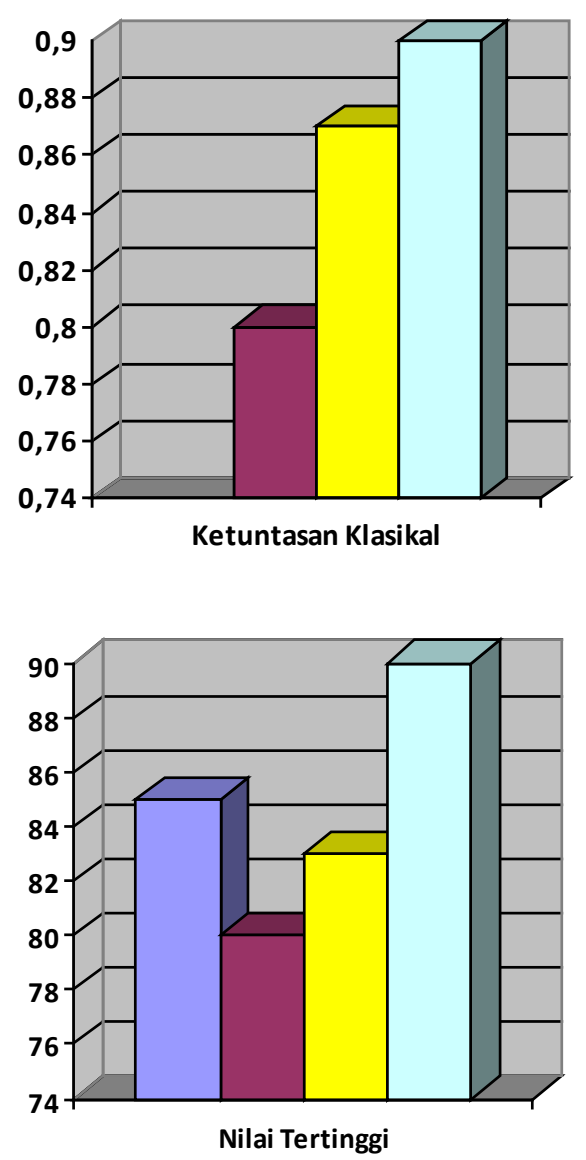
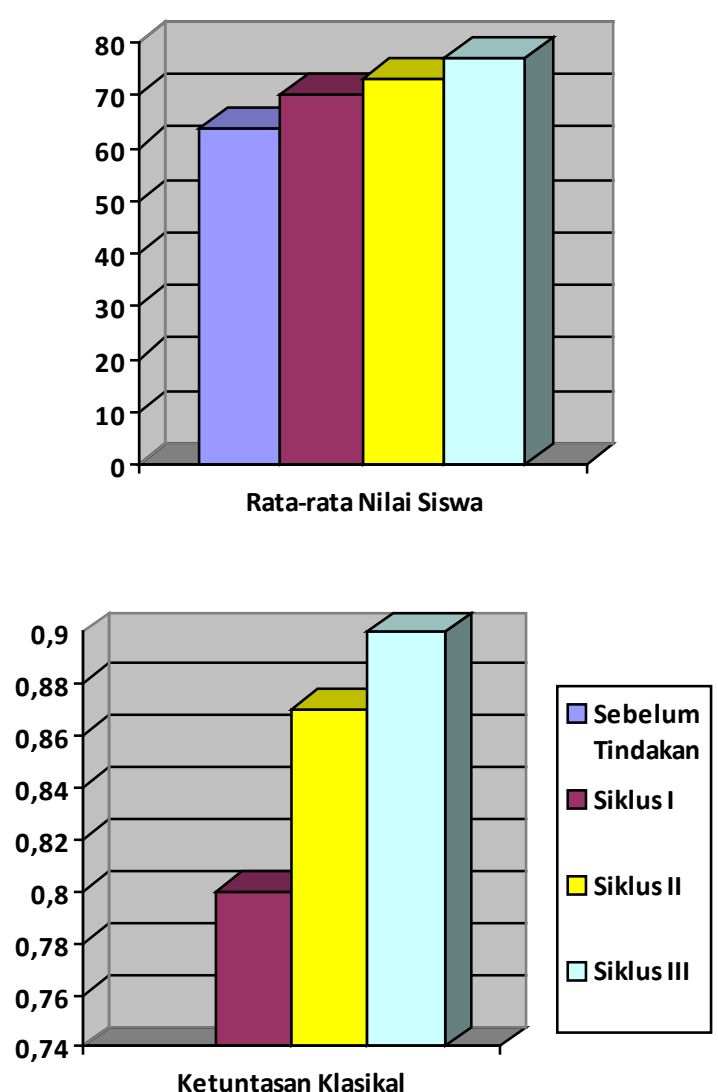

\section{PEMBAHASAN}

Berdasarkan hasil pengamatan diperoleh data bahwa keaktifan siswa selama penelitian pada siklus I, II dan III mengalami peningkatan. Peningkatan keaktifan siswa yang cukup besar karena siswa ikut terlibat langsung dalam kegiatan pembelajaran. Siswa dibagi ke dalam kelompok kecil yang heterogen dengan sebutan anggota kelompok I, II, III, IV, V, VI, VII, VIII, yang masing-masing anggota kelompok mendapat tugas yang berbeda, selanjutnya kelompok ini disebut kelompok asal. Siswa yang mendapat tugas yang sama akan bergabung membentuk kelompok untuk mengerjakan tugas, yang selanjutnya kelompok ini disebut kelompok ahli. Setelah siswa selesai bekerja dalam kelompok ahli, siswa akan kembali ke kelompok asal untuk menjelaskan hasil kerjanya kepada anggota kelompoknya. Selanjutnya diadakan diskusi kelas untuk menyatukan kerangka berpikir dan mengambil kesimpulan yang dibimbing oleh guru, maksudnya penegasannya dibantu oleh guru. Hasil penelitian Chalimah (2006) bahwa 
dengan menerapkan pembelajaran kooperatif tipe Jigsaw akan meningkatkan keaktifan siswa dalam proses pembalajaran.

Pembelajaran kooperatif tipe Jigsaw didesain untuk meningkatkan rasa tanggung jawab siswa terhadap pembelajarannya dan pembelajaran orang lain. Dengan pembelajaran kooperatif tipe Jigsaw juga menumbuhkan saling menghargai, saling membantu, dan penerimaan individu menjadi lebih besar, mengurangi sikap individualisme, dan mengurangi sikap apatis (Slavin, 2009:104).

Keaktifan siswa dalam kelompok pada siklus I masih kurang dan masih belum optimal. Faktor yang menyebabkan kekurangaktifan siswa dalam kelompok, karena siswa baru beradaptasi dengan kelompoknya, baik pada saat diskusi kelompok asal maupun diskusi kelompok ahli, siswa kurang membaca buku pegangan siswa (kurang memahami apa yang telah ia pelajari), dan kurang terbiasa dengan model pembelajaran ini. Siswa merasa takut, kurang percaya diri dan malu, sehingga siswa terkesan seperti orang membaca catatan dan berakibat kurang jelasnya pengertian yang diterima anggota kelompok yang lainnya. Chalimah (2006) menyatakan bahwa pelaksanaan belajar secara kelompok pada tahap awal akan menemui kesulitan apalagi ada sikap anggota kelompok yang negatif akan berpengaruh pada anggota lainnya sehingga tujuan pembelajaran tidak tercapai. Sedangkan Hasibuan dan Moedjiono (Fajar, 2006:42), berpendapat bahwa bagi mereka yang belum terbiasa dengan penggunaan metode kerja kelompok dan masih terbiasa dengan penggunaan metode ceramah memerlukan waktu untuk berlatih.

Interaksi siswa dalam satu kelompok pada siklus II sudah lebih baik dari siklus I yaitu lebih banyak siswa yang saling bekerja sama, sikap menghargai dan mengajukan pertanyaan atau menjawab pertanyaan siswa terlihat sangat antusias dalam melakukan diskusi dan memiliki motivasi yang besar untuk memahami materi pelajaran. Hasil penelitian Kustanti (Fajar, 2006:42), menyatakan bahwa penerapan strategi Jigsaw dapat meningkatkan keaktifan siswa selama proses pembelajaran berlangsung.

Siswa yang kurang aktif pada siklus II juga mengalami penurunan. Siswa yang kurang aktif mungkin juga karena kurang cocok dengan kelompoknya atau memang termasuk siswa yang kurang terbiasa dengan belajar kelompok.
Atau mungkin siswa tersebut sedang tidak baik secara fisik maupun psikis atau masih belum belajar dengan baik.

Keaktifan siswa pada siklus III mengalami peningkatan dari siklus sebelumnya. Peningkatan keaktifan siswa karena mereka telah mengerti dan sudah terbiasa dengan model pembelajaran kooperatif tipe Jigsaw, sehingga siswa tidak lagi canggung dalam mengerjakan tugasnya dan tidak takut dalam menjelaskan materi yang menjadi tugasnya kepada teman sekelompoknya. Tingkat keaktifan siswa yang tinggi pada siklus III karena pelaksanaan pembelajaran sudah sesuai dengan rencana pembelajaran (RPP). Kesesuaian pelaksanaan pembelajaran dengan RPP ini menurut Joyce dan Weil (Fajar, 2006:41) karena: (1) melatih siswa untuk saling kerja sama, (2) anggota kelompok kerja sama dapat saling belajar sesamanya, (3) kerja sama meningkatkan rasa soladaritas, membangun hubungan yang positif terhadap orang lain, (4) kerja sama meningkatkan rasa percaya diri dalam peningkatan pembelajaran dan meningkatkan perasaan dihargai dan perhatian oleh orang lain dalam lingkungannya, dan (5) kerja sama meningkatkan motivasi siswa untuk belajar. Selanjutnya dapat ditegaskan bahwa penerapan pembelajaran kooperatif tipe Jigsaw dapat meningkatkan keaktifan siswa selama pembelajaran pada KD klasifikasi makhluk hidup.

\section{KESIMPULAN DAN SARAN}

Hasil penelitian dan pembahasan membawa pada suatu kesimpulan bahwa penerapan pembelajaran kooperatif tipe Jigsaw dapat meningkatkan hasil belajar KD Klasifikasi Makhluk Hidup di SMP Negeri 1 Gandusari Blitar. Hal ini dapat dilihat dari hasil penelitian pada siklus III, yaitu tingkat aktifitas siswa semakin meningkat, dan hasil belajar juga meningkat memenuhi indikator keberhasilan dalam pembelajaran, yaitu nilai rata-rata kelas sebesar 77 dan ketuntasan klasikal 90\% telah memenuhi indikator keberhasilan yaitu $\geq 85 \%$ siswa mendapat nilai 70 .

Berdasarkan kesimpulan di atas, maka disarankan kepada guru untuk menerapkan pembelajaran kooperatif tipe Jigsaw pada materi biologi yang lain dengan catatan bahwa aktifitas siswa selama proses pembelajaran harus senantiasa dikontrol, sehingga siswa benar- 
benar memanfaatkan waktu untuk memahami materi dan aktif selama proses pembelajaran.

\section{DAFTAR RUJUKAN}

Fajar. 2006. Peningkatan Kualitas Pembelajaran Materi Pengelolaan Lingkungan Melalui Pembelajaran Kooperatif tipe Jigsaw. Skripsi tidak diterbitkan. Semarang: MIPA Universitas Negeri Semarang.
Sanjaya, W. 2006. Strategi Pembelajaran Berorientasi Standar Proses Pendidikan. Jakarta: Kencana Prenada Media Group.

Slavin, R. E. 2009. Cooperative Learning, Teori, Riset dan Praktik. Bandung: Nusa Media.

Trianto. 2007. Model-Model Pembelajaran Inovatif Berorientasi Konstruktivistik. Surabaya: PT Prestasi Pustaka. 
80 | Sri Harwidiastuti, Penerapan Model Pembelajaran Kooperatif Tipe Jigsaw ... 